\title{
PENDIDIKAN KARAKTER MELALUI MEDITASI METODE KITAB SUCI METODE IGNATIUS LOYOLA DAN METODE TERESIA AVILA BAGI CALON GURU AGAMA KATOLIK
}

\author{
Albert I Ketut Deni Wijaya ${ }^{1)}$ dan Natalis Sukma Permana $\left(^{2)}\right.$ \\ ${ }^{1,2}$ Ilmu Pendidikan Teologi, STKIP Widya Yuwana \\ 1,2 Jl. Soegijopranoto, Madiun, Jawa Timur \\ E-mail : albert.deni@widyayuwana.ac.id ${ }^{1)}$, natalisukma@widyayuwana.ac.id ${ }^{2)}$
}

\begin{abstract}
ABSTRAK
Peran guru dalam pendidikan karakter sangat penting. Melalui pendidikan karakter, guru diharapkan menjadi pribadi yang membuka alam dan pikir serta jiwa, mampu mencerahkan, memupuk nilai-nilai keteladanan, nilai-nilai perilaku, nilai-nilai kasih sayang, nilai-nilai moralitas, serta nilai-nilai kebhinekaan. Mengingat guru menjadi kunci sukses pendidikan karakter, maka perlu dipikirkan bagaimana menyiapkan atau mendidik calon guru yang berkarakter unggul. Melalui Program Penguatan Pendidikan Karakter, terdapat 5 nilai karakter yang bersumber dari Pancasila yang dapat dikembangkan dalam pendidikan calon guru agama katolik, yaitu nilai karakter religius, nasionalisme, integritas, mandiri dan gotong-royong. Pendidikan karakter bagi calon guru, khususnya guru agama katolik tidak cukup hanya melalui pembiasaan. Perlu upaya internalisasi juga, salah satunya melalui kegiatan meditasi. Terdapat tiga metode meditasi yang sering digunakan dalam pembinaan calon guru agama katolik, yaitu metode kitab suci, metode Ignatius Loyola dan metode Teresia Avila. Penelitian dilakukan dengan metode kualitatif deskriptif dengan responden adalah mahasiswa calon guru agama katolik. Hasil penelitian menunjukkan bahwa metode yang paling banyak digunakan dalam kegiatan meditasi adalah metode kitab suci. Penelitian juga menunjukkan bahwa kegiatan meditasi dapat mengembangkan karakter religius, nasionalisme, integritas, mandiri dan gotong-royong bagi calon guru agama katolik.
\end{abstract}

Kata Kunci: Pendidikan Karakter; Meditasi; calon Guru Agama Katolik

\section{PENDAhUluaN}

Dalam tulisannya tentang pendidikan karakter bagi calon guru (Wijaya \& Gaudiawan, 2020b) menuliskan bahwa pendidikan karakter bagi seorang calon guru itu penting. Hal ini tentunya mempertimbangkan bagaimana tugas dan tanggung jawab yang harus diemban ketika nanti menjadi guru. Dalam pendidikan karakter, guru harus menjadi sosok yang mencerahkan, yang membuka alam dan pikir serta jiwa, memupuk nilai-nilai kasih sayang, nilai-nilai keteladanan, nilai-nilai perilaku, nilainilai moralitas, nilai-nilai ke bhineka. Hal ini dilakukan sebab guru merupakan kunci sukses pendidikan karakter. Sehubungan dengan itu, perlu dipikirkan bagaimana menyiapkan atau mendidik calon guru yang berkarakter unggul.

Menjadi guru adalah sebuah profesi sekaligus tugas panggilan yang suci (Wijaya \& Gaudiawan, 2020a). Profesi berarti suatu pekerjaan yang membutuhkan keahlian khusus dan tidak dapat dilakukan oleh sembarang orang. Sedangkan guru sebagai panggilan suci mengingat menjadi guru berarti harus sudah siap menemani, melayani, membimbing dan mengarahkan para peserta didik dengan sepenuh hati. Sikap ini tentu tidak lepas dari sikap Tuhan sendiri yang senantiasa mengasihi manusia dengan sepenuh hati.

Berprofesi sebagai guru yang selalu melayani dengan sepenuh hati bukanlah hal yang mudah. Berbagai tantangan siap menghadang dan tentu harus dihadapi dan diatasi. (Wijaya \& Gaudiawan, 2020a) beberapa hal: "Pertama, menjadi seorang guru harus bisa melayani semua lapisan masyarakat. Kedua, menjadi seorang guru tidak hanya mengajar dengan kata-kata namun juga sikap, tingkah laku dan perbuatan. Ketiga, lebih mengutamakan siswa dari pada materi".

Saat ini profesi seorang guru dipandang tidak hanya mengajar atau mendidik saja. Dewasa ini peran guru semakin luas. Guru dituntut untuk berperan sebagai pengajar, pembimbing, pemimpin, ilmuwan, pribadi, penghubung, pembaharu dan pembangun (Wahyuni, 2014).

Akhir-akhir ini terdapat beberapa kasus yang mencoreng profesi guru sebagai panggilan yang suci. Ada kasus guru mencabuli murid (Indonesia, 2021a); Guru melakukan pedofilia (Indonesia, 2021b); guru melakukan kekerasan sampai siswa meninggal (Rachmawati, 2021) dan lain sebagainya. Apa yang ditampilkan pada berita tersebut tentu merupakan informasi yang jelas-jelas bertentangan dengan profesi guru sebagai panggilan yang suci. Setiap orang pasti akan mempertanyakan dimana letak kesucian dari panggilan guru. Kasus-kasus tersebut jika dilihat lebih jauh sesungguhnya tidak terlepas dari permasalahan karakter guru. 
Dari gambaran tersebut menunjukkan bahwa tugas dan tanggung jawab guru begitu besar dan penting. Tidaklah cukup menjadi guru yang pandai dan terampil saja. Guru juga dituntut memiliki karakter yang unggul. Agar guru dapat menyiapkan diri dalam tugasnya tersebut, maka perlu dipersiapkan sejak dari masa pendidikan. Sehubungan dengan hal tersebut maka pendidikan karakter menjadi penting bagi calon guru.

Pendidikan karakter bagi calon guru tidak cukup hanya melalui pembiasaan. Perlu upaya bagaimana pembiasaan itu menginternalisasi. Upaya yang dapat dilakukan agar pendidikan karakter dapat menginternalisasi adalah melalui meditasi. Kegiatan meditasi dirasa akan dapat membantu karena dalam meditasi dimungkinkan terjadinya proses meresapkan pengalaman dan kebiasaan yang telah dilakukan lewat pendidikan karakter.

\section{RUANG LINGKUP}

Setidaknya terdapat empat hal yang menjadi alasan mengapa penelitian ini menjadi penting (RI, 2017). Pertama, penelitian tentang pendidikan karakter menjadi salah satu pendukung program prioritas pemerintah Presiden Joko Widodo dalam Penguatan Karakter. Sehubungan dengan hal tersebut telah banyak dilakukan penelitian dengan tema pendidikan karakter bagi peserta didik di SD, SMP sampai SMA/SMK.

Kedua, peran guru dalam pendidikan karakter sangat penting. Joko Widodo selaku Presiden Indonesia mengatakan dalam pembukaan Rembuk Nasional Pendidikan dan Kebudayaan 2017: "Peran guru sangat penting dalam pendidikan dan ia harus menjadi sosok yang mencerahkan, yang membuka alam dan pikir serta jiwa, memupuk nilai-nilai kasih sayang, nilai-nilai keteladanan, nilai-nilai perilaku, nilai-nilai moralitas, nilai-nilai ke bhineka-an. Inilah sejatinya pendidikan karakter yang menjadi inti dari pendidikan yang sesungguhnya" (RI, 2017). Mengingat guru menjadi kunci sukses pendidikan karakter, maka perlu dipikirkan bagaimana menyiapkan atau mendidik calon guru yang berkarakter unggul.

Ketiga, menjadi guru, khususnya guru Agama Katolik tidak hanya mentransfer ilmu namun juga harus mampu menjadi teladan hidup atau menjadi guru yang berkarakter unggul. Pendidikan karakter bagi calon guru dalam hal ini menjadi penting. Kegiatan meditasi dipandang dapat membantu dalam pendidikan karakter calon guru agama katolik. Dengan demikian para calon guru tersebut nantinya tidak hanya menjadi pengajar ilmu namun memberikan teladan akan nilai-nilai keagamaan yang luhur melalui kata-kata dan perbuatan. Selain itu pula, melalui meditasi para calon guru agama Katolik diharapkan mampu melihat profesi guru merupakan profesi yang mulia. Menjadi seorang guru tidak hanya untuk memenuhi kebutuhan hidup namun sungguh-sungguh merupakan panggilan untuk melayani para peserta didik.
Keempat, tidak banyak penelitian yang mendalami Pendidikan karakter bagi calon guru. Harus diakui tidak banyak penelitian yang mendalami pendidikan karakter bagi calon guru, khususnya calon guru agama katolik. Padahal telah disampaikan bagaimana pentingnya peran guru terlebih lagi guru agama Katolik dalam pendidikan karakter.

Berdasarkan pemaparan di dapat dirumuskan permasalahan yang hendak didalami. Rumusan masalah pertama, bagaimana bentuk kegiatan meditasi yang sesuai untuk pendidikan karakter calon guru agama katolik. Pertanyaan ini perlu digali mengingat terdapat berbagai bentuk meditasi. Agar seorang calon guru agama katolik memiliki karakter yang baik, tentu memerlukan bentuk kegiatan meditasi yang bersifat lebih religius dan mengena bagi pengembangan karakter.

Rumusan kedua, bagaimana dampak kegiatan meditasi dalam pendidikan karakter calon guru agama katolik? Pertanyaan ini penting untuk digali supaya dapat mengetahui apa saja dampak atau manfaat dari kegiatan meditasi bagi pendidikan karakter para calon guru agama katolik. Sebab jangan sampai sebuah kegiatan yang baik dilakukan tanpa diketahui secara pasti apa dampaknya atau manfaatnya.

Penelitian ini memiliki 2 tujuan yang hendak diraih. Pertama, mengetahui bentuk kegiatan meditasi yang sesuai untuk pendidikan karakter calon guru agama katolik. Kedua, mengetahui dampak kegiatan meditasi dalam pendidikan karakter calon guru agama Katolik.

\section{BAHAN DAN METODE}

Bagian ini akan menguraikan berbagai bahan dan metode. Bahan dan metode yang digunakan adalah sebagai berikut:

\subsection{Pendidikan Karakter Bagi Calon Guru}

Karakter pada manusia dapat dikaitkan dengan tabiat, watak, sifat-sifat kejiwaan, akhlak atau budi pekerti seseorang yang dapat membedakan pribadi tersebut dengan orang lain. Karakter manusia tampak melalui berbagai atribut ataupun pola tingkah laku individu. Pola tingkah laku tersebut meliputi sifat kejiwaan, akhlak dan budi pekerti yang menjadikan seseorang terlihat berbeda dari orang lain. Perlu diingat bahwa karakter seseorang bukan sesuatu yang ada atau dibawa sejak lahir. Karakter seseorang terbentuk lewat proses pembelajaran yang cukup panjang di tengah lingkungan tempat manusia tinggal. Dengan demikian, karakter "merupakan ciri, gaya, sifat, ataupun karakteristik diri seseorang yang berasal dari bentukan ataupun tempaan yang didapatkan dari lingkungan sekitarnya. Karakter dibentuk melalui proses pembelajaran yang bersumber dari lingkungan keluarga, lingkungan sekitar tempat tinggal, masyarakat, dan lain-lainnya" (Agung, 2017).

Pendidikan karakter sangat penting dalam pembentukan kepribadian sekaligus menjadi fondasi utama dalam membangun manusia Indonesia yang bertakwa dan siap bersaing di masa depan. Bagi para 
calon guru, khususnya calon guru agama katolik pendidikan karakter menjadi sangat penting. Hal ini mengingat bahwa mereka nantinya akan menjadi fasilitator dari program pendidikan karakter yang dilakukan oleh pemerintah lewat program Penguatan Pendidikan Karakter. Sebagai Fasilitator, tentunya mereka harus lebih dahulu memahami dan menghidupi nilai-nilai karakter yang hendak ditanamkan kepada para peserta didik (Murniyetti dkk, 2016).

Program Penguatan Pendidikan Karakter (PPK) adalah program Kementerian Pendidikan dan Kebudayaan sejak tahun 2010. Pembentukan karakter bangsa melalui program PPK dilaksanakan secara sistematis, masif serta terintegrasi mencakup seluruh sistem pendidikan, budaya di sekolah dan perlu bekerja sama dengan komunitas. Dengan demikian program PPK semakin dapat menumbuhkan semangat belajar para peserta didik. Selain itu, para peserta didik semakin senang berada di sekolah dan menjadikan sekolah layaknya rumah yang ramah bagi bertumbuh dan berkembang pengetahuan mereka (Agung, 2017).

Program PPK sendiri memiliki lima nilai utama karakter yang hendak dikembangkan. Kelima nilai ini bersumber dari Pancasila. Kelima karakter tersebut yaitu religius, nasionalisme, integritas, mandiri dan gotongroyong. Masing-masing nilai utama karakter yang dikembangkan tidak berdiri dan berkembang sendirisendiri. Kelimanya saling berinteraksi satu sama lain, berkembang secara dinamis dan membentuk keutuhan pribadi (RI, 2017).

Berikut ini penjelasan dari kelima nilai karakter dari program Penguatan Pendidikan karakter yang ditetapkan oleh Kementerian Pendidikan dan Kebudayaan Republik Indonesia (RI, 2017). Pertama nilai karakter religius. Nilai karakter ini mencerminkan ke beriman terhadap Tuhan yang Maha Esa yang diwujudkan dalam perilaku melaksanakan ajaran agama dan kepercayaan yang dianut, menghargai perbedaan agama, menjunjung tinggi sikap toleran terhadap pelaksanaan ibadah agama dan kepercayaan lain, hidup rukun dan damai dengan pemeluk agama lain. Implementasi nilai karakter religius ini ditunjukkan dalam sikap cinta damai, toleransi, menghargai perbedaan agama dan kepercayaan, teguh pendirian, percaya diri, kerja sama antar pemeluk agama dan kepercayaan, anti perundungan dan kekerasan, persahabatan, ketulusan, tidak memaksakan kehendak, mencintai lingkungan, melindungi yang kecil dan tersisih.

Kedua, nilai karakter nasionalis. Nilai karakter nasionalis merupakan cara berpikir, bersikap, dan berbuat yang menunjukkan kesetiaan, kepedulian, dan penghargaan yang tinggi terhadap bahasa, lingkungan fisik, sosial, budaya, ekonomi, dan politik bangsa, menempatkan kepentingan bangsa dan negara di atas kepentingan diri dan kelompoknya. Pribadi yang memiliki nilai nasionalis terlihat melalui sikap mengapresiasi kebudayaan bangsa sendiri, sikap menjaga aneka ragam kekayaan budaya bangsa, sikap rela berkorban, bersikap unggul, dan berprestasi, mencintai tanah air, berusaha menjaga lingkungan, menaati aturan hukum yang berlaku, disiplin, menghormati keragaman budaya, agama, dan suku di Indonesia.

Ketiga, nilai karakter integritas. Nilai integritas merupakan nilai yang mendasari perilaku pada upaya menjadikan dirinya sebagai orang yang selalu dapat dipercaya dalam perkataan, tindakan, dan pekerjaan, memiliki komitmen dan kesetiaan pada nilai-nilai kemanusiaan dan moral. Nilai karakter integritas ini dapat meliputi sikap bertanggung jawab sebagai warga negara Indonesia, bersikap aktif terlibat dalam kehidupan sosial di masyarakat, bersikap konsisten dalam kata dan tindakan berdasarkan kebenaran. Seorang yang memiliki nilai integritas tentu juga akan menghargai martabat pribadi manusia, secara khusus para kaum disabilitas. Selain itu mereka juga mampu menunjukkan sikap keteladanan.

Keempat, nilai karakter mandiri. Nilai mandiri merupakan sikap serta perilaku yang tidak bergantung pada orang lain. Sebagai pribadi yang mandiri, ia akan mempergunakan segala tenaga, pikiran, waktu untuk dapat mewujudkan segala harapan, impian dan cita-cita. Pribadi yang mandiri akan memiliki etos kerja yang baik, berdaya juang, tangguh, profesional, kreatif, berani dan senantiasa menjadi pembelajar sepanjang hayat.

Kelima, nilai karakter gotong royong. Nilai gotong royong ini mencerminkan tindakan menghargai semangat kerja sama dan bahu membahu menyelesaikan persoalan bersama, menjalin komunikasi dan persahabatan, memberi bantuan/pertolongan pada orang-orang yang membutuhkan. Diharapkan siswa dapat menunjukkan sikap menghargai sesama, dapat bekerja sama, inklusif, mampu berkomitmen atas keputusan bersama, musyawarah mufakat, tolong menolong, memiliki empati dan rasa solidaritas, anti diskriminasi, anti kekerasan, dan sikap ke relawanan.

Agar program PPK dapat berjalan dengan baik, para calon guru yang nantinya akan menjadi fasilitator harus sungguh-sungguh menginternalisasi nilai-nilai karakter di atas. Agar nilai-nilai karakter dapat menginternalisasi dibutuhkan pembiasaan. Pembiasaan menjadi hal yang perlu dilakukan mengingat juga bahwa karakter mencakup tiga bagian yang meliputi pengetahuan moral (moral knowing), pengetahuan rasa (feeling knowing) dan moral perilaku (moral behaviour). Selain itu pula, proses pembinaan ketiga bagian tersebut tidak dapat langsung jadi (Wijaya \& Gaudiawan, 2020b).

\subsection{Kegiatan Meditasi}

Secara etimologis kata meditasi berasal dari bahasa Latin yaitu meditare yang berarti berpikir-pikir sampai menembus permukaan hingga menemukan inti (medium). Kata lain dari meditasi yang memiliki arti serupa adalah merenung, bersemadi. Kamus Besar Bahasa Indonesia mengartikan meditasi sebagai aktivitas pemusatan pikiran dan perasaan untuk mencapai sesuatu. 
Nasa \& Nuwa sebagaimana mengutip Suryani mengatakan bahwa "meditasi merupakan aktivitas pemusatan pikiran kepada satu objek tertentu dengan kesadaran penuh, sehingga mampu dirasakan bagaimana proses itu berefek pada tubuhnya" (Nasa \& Nuwa, 2019). Sedangkan menurut Walsh \& Shapiro yang juga masih di ikuti dari Nasa \& Nuwa (2019) dikatakan "meditasi adalah praktik pengaturan diri yang berfokus melatih perhatian dan kesadaran dengan maksud membawa proses pemikiran kedalam kontrol secara sukarela yang lebih besar dan dengan demikian mendorong kesejahteraan rohani secara umum dan mengembangkan kemampuan tertentu seperti ketenangan, kejernihan, dan konsentrasi".

Bagi orang Katolik, kegiatan meditasi diartikan dengan sedikit berbeda. Meditasi diartikan sebagai kegiatan doa batin dimana hal itu dilakukan dengan cara merenungkan Kitab Suci untuk dapat mencapai kesatuan dengan Allah dan mendapatkan pemahaman atas kehendak Allah.

Kegiatan meditasi dapat dilakukan dengan memperhatikan tiga langkah sederhana. Pertama, menentukan tempat dan posisi badan yang memungkinkan tubuh rileks dan tidak tertidur. Kedua, memberi perhatian kepada pernafasan dimana terjadi proses menghirup udara dan mengeluarkan udara lewat pernafasan. Ketiga, berlatih terus-menerus secara sabar mengingat meditasi membutuhkan latihan dan kesabaran (Buchanan, 2017).

\subsection{Metode Meditasi bagi Calon Guru Agama Katolik}

Dalam kegiatan meditasi bagi calon Guru Agama Katolik, setidaknya terdapat 3 metode meditasi yang dapat dilakukan. Ketiga metode tersebut yaitu: metode Kitab Suci, metode Santa Teresia Avila, dan metode latihan rohani dari Ignasius Loyola.

1. Meditasi metode Kitab Suci

Meditasi dengan metode kitab suci, adalah meditasi yang dilakukan dengan 3 langkah. Langkah pertama peserta diajak untuk melakukan persiapan dengan membaca bacaan rohani. Langkah kedua peserta diajak untuk melakukan pengamatan, penalaran dan pengamalan. Akhirnya langkah ketiga diisi dengan wawancara batin (Dirja, 2019).

2. Meditasi metode Ignatius Loyola

Secara garis besar, metode Ignatius Loyola atau metode latihan hidup rohani santo Ignasius Loyola terdiri dari lima latihan. Setiap hari orang diharapkan mengadakan lima kali latihan dengan kerangka sebagai berikut: Latihan pertama dengan bahan pertama. Bahan yang dimaksud bisa berupa pengalaman, dan terutama Sabda Allah. Latihan kedua dengan bahan kedua. Bahan latihan yang dimaksud berupa pengalaman, dan terutama Sabda Allah. Cara latihannya sama dengan pedoman meditasi Alkitabiah (yang telah di jelaskan di atas). Latihan ketiga adalah latihan bahan pertama dan kedua, dengan lebih memperhatikan dan berhenti pada pokok, dimana dirasakan adanya hiburan atau kesepian, yang lebih besar, atau pengalaman rohani yang lebih besar. Lalu diadakan wawancara. Metode wawancara telah dibahas di atas pada sub-bahasan ini. Latihan keempat: membuat resume latihan ketiga dengan penjelasan sebagai berikut: ringkasan maksud pelaku meditasi supaya pikiran, tanpa mencari hal-hal lain, menelaah dengan tekun kesan dari hal-hal yang telah direnungkan dalam latihan yang sudah-sudah. Latihan kelima: mengenakan pancaindera. Pada langkah satu sampai empat, Ignasius sangat menekankan mencecap pengalaman serta gerak-gerak batin, sedangkan pada langkah kelima ini Ignasius mengharapkan kesan atau meresapkan pengalaman latihan yang kuat dengan mengenangkan pancaindera.

3. Meditasi metode Teresia Avila

Meditasi dengan metode Teresia Avila memiliki 3 langkah. Langkah pertama melakukan persiapan. Pada langkah ini perlu menyediakan waktu untuk Tuhan. Pilihlah satu tempat yang tenang. Tinggalkan kesibukan pikiran yang berkecamuk atas pekerjaan dan keinginan lainnya. Ambil posisi-posisi duduk yang nyaman. Rileks badan dan pikiran dengan mengatur pernapasan yang berirama dan teratur baik. Sadarilah diri, pernapasan dan posisi duduk. Letakkan tangan di atas paha atau angkat sebatas dada. Buka telapak menghadap atas tanda siap menerima segala rahmat, menerima Allah. Pejamkan mata. Ambil napas yang dalam dan lepaskan perlahan. Ulangi cara bernapas ini beberapa kali untuk me-rileks badan dan pikiran dan untuk melatih konsentrasi (Surinono, 2019).

Langkah kedua bertemu dengan Tuhan. Setelah melakukan persiapan, saatnya memusatkan pikiran kepada Tuhan. Yakinkan diri bahwa Allah ada di kedalaman batin, yang ingin berbicara dan mendengarkan segala kerinduan terdalam. Nikmatilah kebersamaan dengan Yesus sahabat terbaik. Sekali lagi sadarilah dengan sungguh akan kehadiran Tuhan. Pikiran dapat dibantu untuk tidak akan kemana-mana dan tetap sadar dengan doa-doa vokal secara perlahan dan penuh kesadaran dalam pikiran. Doa vokal yang disarankan antara lain Salam Maria dan Bapa Kami atau doa-doa singkat yang bernapaskan Sabda Allah.

Langkah ketiga saling berbagi. Pendoa akan terdorong untuk berbicara Yesus ketika memandang Yesus dengan penuh iman dan kasih, dan pada saat ini harus terjadi kesadaran diri dan juga menyadari siapa Dia yang mendengarkan Anda. Bicaralah kepada Tuhan dengan yakin sebagai Bapa atau saudaramu, sebagai kekasih atau sebagai teman terbaik. Bicaralah tentang apa saja: menyampaikan rasa syukur dan terima kasih, atau meminta berkat dan rahmat-Nya agar bisa kuat, sehat, sukses, setia, mengampuni sesama, kuat, jujur, sabar dan lain-lain.

Penelitian ini menggunakan metode kualitatif deskriptif. Penelitian akan terbagi menjadi 6 tahap. Tahap pertama diawali dengan Studi literatur guna memperdalam dan mempertajam teori-teori pendukung 
penelitian. Tahap selanjutnya adalah observasi. Dalam tahap ini peneliti melakukan persiapan guna pemantapan proses pengambilan data dengan membangun komunikasi dan koordinasi dengan para calon responden. Tahap selanjutnya pengambilan data. Hasil pengumpulan data pada tahap selanjutnya dianalisis. Setelah proses analisis peneliti membuat laporan hasil penelitian.

Responden penelitian adalah para mahasiswa calon guru agama katolik. Para mahasiswa tersebut menempuh studi pada Prodi yang terdapat pada STKIP Widya Yuwana, Unika Atma Jaya Jakarta, Universitas Sanata Dharma Yogyakarta dan Unika Santu Paulus Ruteng.

Analisis penelitian kualitatif bersifat induktif. Proses pengambilan kesimpulan disusun melalui berbagai informasi yang didapatkan dari lapangan. Proses analisis ini terjadi secara bersama dari proses pengumpulan data sampai dengan penyusunan laporan. Setiap data yang didapatkan akan disesuaikan dengan tujuan penelitian supaya diperoleh keterkaitan nya.

\section{PEMBAHASAN}

Pada bagian pembahasan ini akan memaparkan berbagai hasil yang diperoleh dari kegiatan penelitian berdasarkan rumusan masalah yang telah disampaikan pada bagian pendahuluan. Pembahasan hasil penelitian terbagi menjadi 2 bagian yaitu, pertama hasil penelitian tentang kegiatan meditasi yang sesuai untuk pendidikan karakter calon guru agama katolik; kedua, hasil penelitian dari dampak kegiatan meditasi dalam pendidikan karakter calon guru agama katolik

\subsection{Kegiatan Meditasi Yang Sesuai Untuk Pendidikan Karakter Calon Guru Agama Katolik.}

Berdasarkan hasil penelitian diperoleh data bahwa kegiatan meditasi yang paling banyak dilakukan adalah meditasi dengan metode Kitab Suci. Meskipun metode meditasi Kitab Suci adalah metode yang paling banyak dilakukan, bukan berarti 2 metode lainnya, yaitu metode santo Ignatius Loyola dan Santa Theresia Avila tidak baik.

Sebagaimana telah disampaikan, bahwa meditasi dengan metode ini memiliki 3 langkah. Pertama, langkah persiapan yang terdiri dari membaca bahan, mengheningkan diri, dan mohon rahmat khusus. Membaca bahan yang dimaksud adalah memilih kutipan Sabda Allah yang akan di meditasi. Kutipan yang dipilih dibaca dengan lancar dan tenang, dibaca ulang sekali lagi lewat tanpa direnungkan.

Kedua, langkah pokok meditasi. Pada langkah ini yang dilakukan adalah pengamatan, penalaran, dan pengamalan. Langkah ini disebut langkah pokok karena meminta paling banyak waktu dan usaha yang aktif, menyelidiki dan mencermati sehingga pemahaman sedapat mungkin objektif, berperan (masuk) pada Sabda Tuhan dan pesan-Nya. Pada tahap pengamatan terjadi usaha menemukan sendiri apa yang tertulis dari Sabda yaitu kata-kata kunci yang penting dan mengandung inti kalimat seperti peringatan atau larangan, ajakan, janji, teguran, lukisan, contoh, perbandingan, pengulangan, bahkan kata yang kurang dipahami yang menimbulkan pertanyaan, dan memerlukan penjelasan lebih lanjut. Pada bagian terjadi usaha untuk menemukan sendiri apa yang dimaksud Tuhan yaitu menemukan penjelasan atau menjawab pertanyaan yang muncul pada tahap pengamatan. Penjelasan terhadap pertanyaan yang muncul dapat dicari di buku tafsir, ensiklopedi, kamus atau bertanya kepada orang yang lebih tahu. Selanjutnya, merumuskan pesan utama dari seluruh kutipan dengan bahasa dan kata-kata sendiri yang disebut tindakan parafrase, artinya menembus (para) kalimat (frase) (Dirja, 2019). Bagian terakhir dari langkah pokok meditasi adalah pengamalan, yaitu usaha untuk implementasi sehingga hidup diresapi dan dibaharui.

Ketiga, pengarahan terakhir. Pada bagian ini dilakukan dengan wawancara batin. Sesungguhnya langkah ini sangat penting meskipun waktunya sangat singkat. Doa menjadi inti langkah ini, artinya secara personal menanggapi Sabda Tuhan dan inspirasi nya dengan hati dan perasaan yang muncul selama meditasi (Dirja, 2019).

Hasil penelitian juga menunjukkan bahwa ada tanggapan yang melihat bahwa ketiga metode meditasi baik jika digunakan untuk saling melengkapi. Diketahui bahwa masing-masing metode memiliki kekhasan dan keunikan dalam pelaksanaan. Kekhasan dan keunikan dari masing-masing metode hendaknya dilihat sebagai suatu kekayaan yang perlu dialami dan dirasakan. Melakukan kegiatan meditasi dengan menggunakan ketiga metode yang ada setidaknya juga dapat membantu agar kegiatan meditasi tidak membosankan atau menjenuhkan.

\subsection{Dampak Kegiatan Meditasi Dalam Pendidikan Karakter Calon Guru Agama Katolik.}

Berdasarkan hasil penelitian, diperoleh bahwa kegiatan meditasi memiliki dampak dalam pendidikan karakter para calon guru agama katolik. Setidaknya dampak kegiatan meditasi bagi calon guru agama katolik dapat dikelompokkan dalam 5 bagian, dimana kegiatan meditasi meningkatkan karakter religius, karakter nasionalisme, karakter integritas, karakter mandiri dan karakter gotong-royong.

1. Kegiatan meditasi berdampak pada karakter religius calon guru agama katolik.

Sebagaimana disampaikan tentang karakter religius, dimana karakter ini adalah cerminan beriman terhadap Tuhan yang maha kuasa (RI, 2017). Karakter ini terimplementasi dalam sikap cinta damai, toleransi, menghargai perbedaan agama dan kepercayaan, teguh pendirian, percaya diri, kerja sama antar pemeluk agama dan kepercayaan, anti perundungan dan kekerasan, persahabatan, ketulusan, tidak memaksakan kehendak, mencintai lingkungan, melindungi yang kecil dan tersisih.

Para responden berdasarkan hasil penelitian mengungkapkan bahwa melalui kegiatan meditasi 
mereka dapat semakin terbantu untuk mencintai kedamaian; meditasi membantu supaya dapat bersikap toleransi terhadap umat beragama lain; meditasi membantu para responden untuk mampu menghargai perbedaan agama dan kepercayaan yang berbeda; meditasi juga membantu semakin teguh dalam pendirian; meditasi juga membantu dalam menguatkan rasa percaya diri; meditasi membantu para responden untuk dapat bekerja sama antar pemeluk agama dan kepercayaan yang berbeda; Meditasi membantu untuk tidak melakukan perundungan/bullying kepada orang lain; Meditasi membantu agar tidak melakukan kekerasan kepada orang lain; Meditasi membantu agar dapat bersahabat dengan siapa saja; Meditasi membantu agar bersikap tulus; Meditasi membantu agar bersikap tidak memaksakan kehendak pada orang lain; Meditasi membantu agar mencintai lingkungan di sekitar; akhirnya meditasi membantu agar berani melindungi yang kecil dan tersisih.

2. Kegiatan meditasi berdampak pada karakter nasionalisme calon guru agama katolik.

Kementerian Pendidikan dan Kebudayaan RI (2017) menyampaikan "Karakter nasionalis merupakan cara berpikir, bersikap, dan berbuat yang menunjukkan kesetiaan, kepedulian, dan penghargaan yang tinggi terhadap bahasa, lingkungan fisik, sosial, budaya, ekonomi, dan politik bangsa, menempatkan kepentingan bangsa dan negara di atas kepentingan diri dan kelompoknya". Karakter yang memiliki nilai nasionalis terlihat melalui sikap mengapresiasi kebudayaan bangsa sendiri, sikap menjaga aneka ragam kekayaan budaya bangsa, sikap rela berkorban, bersikap unggul, dan berprestasi, mencintai tanah air, berusaha menjaga lingkungan, menaati aturan hukum yang berlaku, disiplin, menghormati keragaman budaya, agama, dan suku di Indonesia.

Sejalan dengan pemaparan di atas, diperoleh hasil bahwa kegiatan meditasi memberi dampak dalam pengembangan karakter nasional. Melalui kegiatan meditasi diperoleh data sebagai berikut: Meditasi membantu dalam mengapresiasi budaya bangsa sendiri; Meditasi membantu agar bersedia menjaga kekayaan budaya bangsa Indonesia; Meditasi membantu agar bersikap rela berkorban bagi bangsa; Meditasi membantu agar menjadi pribadi yang unggul; Meditasi membantu agar cinta tanah air; Meditasi membantu agar berani menjaga lingkungan; Meditasi membantu agar bersikap taat hukum; Meditasi membantu agar mampu bersikap disiplin; Meditasi membantu agar dapat menghormati keragaman budaya di Indonesia; Meditasi membantu dalam menghormati suku-suku di Indonesia; dan meditasi membantu dalam menghormati agama yang berbeda.

3. Kegiatan meditasi berdampak pada karakter integritas calon guru agama katolik.

Kementerian Pendidikan dan Kebudayaan (RI, 2017) juga memaparkan bahwa "nilai integritas merupakan nilai yang mendasari perilaku pada upaya menjadikan dirinya sebagai orang yang selalu dapat dipercaya dalam perkataan, tindakan, dan pekerjaan, memiliki komitmen dan kesetiaan pada nilai-nilai kemanusiaan dan moral". Nilai karakter integritas ini dapat meliputi sikap bertanggung jawab sebagai warga negara Indonesia, bersikap aktif terlibat dalam kehidupan sosial di masyarakat, bersikap konsisten dalam kata dan tindakan berdasarkan kebenaran. Seorang yang memiliki nilai integritas tentu juga akan menghargai martabat pribadi manusia, secara khusus para kaum disabilitas. Selain itu mereka juga mampu menunjukkan sikap keteladanan.

Penelitian yang dilakukan menunjukkan bahwa meditasi memiliki dampak dalam mengembangkan karakter integritas bagi calon guru agama katolik. Adapun dampak yang terlihat yaitu: meditasi membantu agar memiliki sikap tanggung jawab sebagai warga negara Indonesia; Meditasi membantu agar aktif terlibat dalam kehidupan sosial; Meditasi membantu agar bersikap konsistensi dalam tindakan dan perkataan yang berdasarkan kebenaran; Meditasi membantu agar menghargai martabat individu khususnya terhadap penyandang disabilitas; akhirnya meditasi membantu agar berani menunjukkan sikap keteladanan yang baik.

4. Kegiatan meditasi berdampak pada karakter mandiri calon guru agama katolik.

Nilai mandiri merupakan sikap serta perilaku yang tidak bergantung pada orang lain. Sebagai pribadi yang mandiri, ia akan mempergunakan segala tenaga, pikiran, waktu untuk dapat mewujudkan segala harapan, impian dan cita-cita. Pribadi yang mandiri akan memiliki etos kerja yang baik, berdaya juang, tangguh, profesional, kreatif, berani dan senantiasa menjadi pembelajar sepanjang hayat (RI, 2017).

Hasil penelitian yang dilakukan rupanya menunjukkan bahwa kegiatan meditasi juga berdampak pada pengembangan karakter mandiri para calon guru agama. Hasil penelitian yang diperoleh yaitu sebagai berikut: Meditasi membantu agar memiliki sikap etos kerja yang baik; Meditasi membantu agar memiliki sikap tangguh; Meditasi membantu agar memiliki sikap berdaya juang; Meditasi membantu agar memiliki sikap profesional; Meditasi membantu agar memiliki sikap kreatif; Meditasi membantu agar memiliki sikap berani; Meditasi membantu agar memiliki sikap pembelajar sepanjang hayat.

5. Kegiatan meditasi berdampak pada karakter gotongroyong calon guru agama katolik.

Nilai gotong royong merupakan wujud perilaku yang menghargai semangat kerja sama dan bahu membahu menyelesaikan persoalan secara bersama, menjalin komunikasi dan persahabatan, serta memberi bantuan/pertolongan pada orang-orang yang membutuhkan. Buah dari pengembangan nilai karakter gotong royong adalah munculnya sikap menghargai sesama, dapat bekerja sama, inklusif, mampu berkomitmen atas keputusan bersama, musyawarah mufakat, tolong menolong, memiliki empati dan rasa 
solidaritas, anti diskriminasi, anti kekerasan, dan sikap kerelawanan (RI, 2017).

Penelitian yang dilakukan rupanya juga mendapatkan data bahwa kegiatan meditasi berdampak dalam pengembangan nilai karakter gotong royong bagi para calon guru agama katolik. Data yang diperoleh adalah: meditasi membantu agar memiliki sikap menghargai sesama; Meditasi membantu agar memiliki sikap bersedia bekerja sama; Meditasi membantu agar memiliki sikap inklusif; Meditasi membantu agar memiliki sikap berkomitmen atas keputusan bersama; Meditasi membantu agar memiliki sikap berkomitmen atas keputusan bersama; Meditasi membantu agar memiliki sikap tolong menolong; Meditasi membantu agar memiliki sikap empati; Meditasi membantu agar memiliki sikap solidaritas; Meditasi membantu agar memiliki sikap anti diskriminasi; Meditasi membantu agar memiliki sikap anti kekerasan; Meditasi membantu agar memiliki sikap kerelawanan.

\section{KESIMPULAN}

Metode kitab suci merupakan metode yang paling banyak digunakan dalam kegiatan meditasi para calon guru agama katolik. Meskipun demikian tidak berarti bahwa metode ini merupakan satu-satunya metode terbaik, mengingat masing-masing metode meditasi memiliki ke khasnya sendiri. 2 metode meditasi lain bagi calon guru agama katolik yang dapat digunakan yaitu metode Ignatius Loyola dan Teresia Avila..

Kegiatan meditasi juga memiliki dampak bagi pendidikan karakter bagi calon guru agama katolik. Melalui kegiatan meditasi bagi para calon guru agama katolik dapat ditumbuhkan nilai karakter religius, karakter nasionalisme, karakter integritas, karakter mandiri dan karakter gotong-royong. Kelima karakter tersebut merupakan karakter penting yang dikembangkan dari pancasila dan perlu dimiliki oleh para calon guru agama katolik.

\section{SARAN}

Menjadi guru, khususnya guru Agama Katolik tidak hanya mentransfer ilmu namun juga harus mampu menjadi teladan hidup atau menjadi guru yang berkarakter unggul. Pendidikan karakter bagi calon guru dalam hal ini menjadi penting. Kegiatan meditasi dipandang dapat membantu dalam pendidikan karakter calon guru agama katolik.

Pada masa selanjutnya perlu disiapkan desain pendidikan bagi para calon guru agama katolik yang terintegrasi dengan pendidikan karakter salah satunya lewat kegiatan meditasi. Hal ini perlu dilakukan mengingat kegiatan meditasi memiliki dampak bagi pengembangan karakter para calon guru agama katolik. Pembiasaan kegiatan meditasi dapat dilakukan dengan menggunakan metode Kitab Suci, metode Ignatius Loyola maupun metode Teresia Avila.

\section{DAFTAR PUSTAKA}

Agung, I. 2017. Peran fasilator guru dalam penguatan pendidikan karakter ( PPK ) Iskandar Agung The Role Of Teacher Facilator. PERSPEKTIF Ilmu Pendidikan, 31(2), 106-119. https://doi.org/https://doi.org/10.21009/PIP.312.6

Buchanan, T. K. 2017. Mindfulness and Meditation in Education. A Local Study. Young Children, 72(July), 69-74. https://www.researchgate.net/publication/3297150 51_Mindfulness_and_Meditation_in_Education.

Dirja, A. (2019). Meditasi Katolik: Bertemu Tuhan Dalam Keheningan Batin, Melalui Kontemplasi, Meditasi, Doa Kehadiran, Dan Pemeriksaan Batin. Obor.

Indonesia, C. 2021a. Guru Cabuli 7 Murid SD di Nias Sumut Ditangkap Polisi. CNN Indonesia. https://www.cnnindonesia.com/nasional/20211028 140034-12-713616/guru-cabuli-7-murid-sd-dinias-sumut-ditangkap-polisi

Indonesia, C. 2021b. Korban Pedofilia Guru Pesantren di Sumsel Jadi 26 Orang. CNN Indonesia. https://www.cnnindonesia.com/nasional/20210916 160459-12-695347/korban-pedofilia-gurupesantren-di-sumsel-jadi-26-orang

Murniyetti, M., Engkizar, E., \& Anwar, F. 2016. Pola Pelaksanaan Pendidikan Karakter Terhadap Siswa Sekolah Dasar. Jurnal Pendidikan Karakter, 6(2), 156-166. https://doi.org/10.21831/jpk.v6i2.12045

Nasa, R., \& Nuwa, G. 2019. Penguatan Nilai Karakter melalui Kegiatan Meditasi Kitab Suci di Sekolah Menengah Pertama Seminari Maria Bunda Segala Bangsa Maumere Nusa Tenggara Timur. Jurnal Pancasila dan Kewarganegaraan, 4(2), 53-61. https://doi.org/10.24269/jpk.v4.n2.2019.pp53-61

Rachmawati. 2021. Kronologi Siswa SMP Meninggal Usai Dipukul Guru gara-gara Tak Kerjakan PR, Sempat Dirawat 2 Hari di RS. Kompas.Com. https://regional.kompas.com/read/2021/10/26/1303 00478/kronologi-siswa-smp-meninggal-usaidipukul-guru-gara-gara-tak-kerjakan-pr

RI, K. P. dan K. 2017. Penguatan Pendidikan Karakter Jadi Pintu Masuk Pembenahan Pendidikan Nasional. 17-07-2017. https://www.kemdikbud.go.id/main/blog/2017/07/ penguatan-pendidikan-karakter-jadi-pintu-masukpembenahan-pendidikan-nasional

Surinono, C. 2019. Doa Batin bersama St. Teresa dari Avila. Kanisius.

Wahyuni, S. 2014. Profesi Guru Adalah Panggilan Ilahi. Antusias, Jurnal Teologi dan Pelayanan, III(5), 147-160. http://www.sttintheos.ac.id/ejournal/index.php/antusias/article/view/18

Wijaya, A. I. K. D., \& Gaudiawan, A. V. E. 2020a. Dampak Pembelajaran Reflektif Bagi Calon Guru Agama Katolik Terhadap Panggilan. JPAK, 20, 101-112. https://doi.org/https://doi.org/10.34150/jpak.v20i1. 
259

Wijaya, A. I. K. D., \& Gaudiawan, A. V. E. 2020b. Reflective Learning as a Model of Character Education for the Teacher Candidate in the Industrial Revolution 4.0. 465(Access 2019), 190193. https://doi.org/10.2991/assehr.k.200827.048

\section{UCAPAN TERIMA KASIH}

Terima kasih kepada Kemendikbud Ristek yang telah membiayai penelitian ini. Terima kasih pula kepada rekanrekan mahasiswa calon guru agama katolik dari STKIP Widya Yuwana, Unika Sanata Dharma, Unika Indonesia Atma Jaya dan Unika Indonesia Santu Paulus Ruteng yang berkenan menjadi responden penelitian. 